\title{
Ideja čovjeka u filozofiji Josefa Piepera
}

\author{
Franjo Mijatović* \\ UDK: 1 Pieper, J. *101 • Izvorni znanstveni rad \\ Primljeno: 30. svibnja 2017. • Prihvaćeno: 4. rujna 2017.
}

Sažetak: U članku će se prije svega ukazati na nekoliko temeljnih pretpostavki i implikacija Pieperova razumijevanja čovjeka, njegove biti i njegova položaja u svijetu, nastojeći objasniti u jednoj sintetizirajućoj filozofijsko-teologijskoj viziji fenomene poput kulture, rada, morala, dokolice... Pri tom će posebna pozornost biti posvećena Pieperovu razumijevanju ljudskoga bića, odnosno teoriji o ljudskoj naravi, koju on razumijeva kao teologijski projekt koji se mora aktualizirati. Ljudska bića, ukoliko su dio božanskoga stvaranja, usmjerena su prema određenom konačnom kraju, odnosno na intimnu vezu sa Stvoriteljem. Stoga Josef Pieper filozofijsku antropologiju oblikuje oko prirodne zadanosti čovjekova tubitka, pri čemu čovjek otkriva svoje čovještvo u ontologijskoj temporalnosti kao cilj i zapovijed svoga života.

${ }^{*}$ Dr. sc. Franjo Mijatović, Teologija u Rijeci - područni studij Katoličkog bogoslovnog fakulteta Sveučilišta u Zagrebu, Omladinska 1, 51000 Rijeka, Hrvatska, fran_mij@yahoo.com

Ključne riječi: Josef Pieper, metafizika stvaranja, ljudska narav, J. P. Sartre, dokolica, biti na putu.

\section{Uvod}

Iako je ideja čovjeka, nedvojbeno, prisutna u svim našim diskursima, čovjek kao predmet i subjekt istraživanja ostaje otvoren mnogovrsnim tumačenjima i interpretacijama. $S$ jedne strane, sam čovjek pokazuje nam se kao neupitna činjenica, a s druge strane, kao polazište antropologijskog problema: Tko je čovjek? Kakav on treba biti? Je li njegovo dostojanstvo ugroženo?... Na neki način pitanje o čovjeku uvijek ostaje nejasan fenomen, budući da istraživanje takvog složenog fenomena ovisi i o nutarnjim i o vanjskim faktorima samog istraživača. Usred raznih ideologijskih utjecaja, očekivanja sredine i društvenih obrazaca interpre- 
tiranja čovjeka, postaje jasnim kako se čovjeka ne može jednoznačno tumačiti. A opet sve ovisi o slici čovjeka koju zastupamo.

Janusovo lice čovještva odražava se i u našem popularnom razmišljanju o čovjeku. Dok čovjeka tumačimo kao najsuperiornije biće na zemlji, odnosno već kao stroj $\mathrm{s}$ nizom genetskih čimbenika i psiholoških mehanizama utvrđenih shema, $\mathrm{s}$ druge strane kršćansko, pa i svako religiozno, razumijevanje čovjeka ovisi o čovjekovom odnosu prema Bogu. Uskraćivanje dostojanstva čovjeku ide ruku pod ruku s nedvosmislenim zahtjevom za što većom izvanjskom i pravnom reprezentacijom dostojanstva ljudskoga bića osobito u političkom prostoru, pri čemu čovjek postaje ključna riječ političkog common sensa koji inzistira na parcijaliziranom promatranju čovjeka, prešutno negirajući njegovo čovještvo. U sklopu poznanstvenjenja cjelokupne čovjekove zbilje mnoge prirodne znanosti naginju k tome da se objektivizira i ljude, svodeći ih na bezlične determinante. Ova dihotomija naše društvene svijesti oblikuje naš mentalitet, štoviše, cjelokupni filozofijsko-znanstveni povijesni kontekst u kojem postaje jasno kako čovjek posebno u okviru današnjih znanstvenih istraživanja nanovo postaje predmetom debata.

Čovjek je i središnje mjesto filozofijskoga fokusa njemačkog filozofa Josefa Piepera, čemu je uostalom i ovaj rad posvećen. Premda se čitava filozofija Josefa Piepera indirektno bavi pitanjem čovjeka, on mu ni u jednom djelu svoga filozofijskoga opusa nije posvetio izričitu i preciziranu pozornost, na način stvaranja jedne sustavne filozofijske antropologije ${ }^{1}$. Posebno to dolazi do izražaja ako se uzme njegovo temeljno djelo posvećeno navedenoj problematici, a što uostalom potvrđuje i sam naslov sveska, Schriften zum Philosophischen Anthropologie und Ethik: Das Menschenbild der Tugendlehre. U navedenom djelu Pieper analizira etički obrazac čovjekova djelovanja, odnosno sliku čovjeka koja bi trebala i morala vrijediti u društvenom uređenju ukoliko hoće dobre građane i kreposne pojedince.

Stoga će ovaj rad, oslanjajući se na filozofijsku antropologiju Josefa Piepera, ponuditi jednu klasičniju viziju čovjeka. U članku će se, prije svega, ukazati na nekoliko temeljnih pretpostavki i implikacija Pieperova razumijevanja čovjeka, čovjekove biti i njegova položaja u svijetu, nastojeći objasniti u jednoj sintetizirajućoj filozofijsko-teologijskoj viziji fenomene poput kulture, rada, morala, koji itekako utječu na naš cjelokupni odnos prema ljudima.

\footnotetext{
${ }^{1} \mathrm{Na}$ Pieperovu filozofijsku antropologiju uvelike su utjecali filozofi poput Tome Akvinskog, Ericha Przyware, Martina Heideggera, Gabriela Marcela... Marcelov je utjecaj osobito vidljiv u Pieperovu prihvaćanju i daljnjem razvoju Marcelove ideje homo viatora. Usp. B. SCHUMACHER, An Introduction to the Philosophy of Josef Pieper, u: ISTI (ur.) A Cosmopolitan Hermit: Modernity and Tradition in the Philosophy of Josef Pieper, Washington D. C., 2009., 11.
} 


\section{Metafizika stvaranja}

Još od antičkih Grka, u našem kontekstu posebno od Platona na kojeg se Pieper poziva kao na jednoga od svoja dva duhovna učitelja, pitanje je o čovjeku ukorijenjeno u metafizici i transcendenciji. Postojeća slika svijeta, kako smatra Pieper, ozbiljuje na jedan paradoksalan način sve ono što je protivno čovjeku kao stvorenom biću. Čovjek je po svojoj prirodi stvoren i kao takvom mu je već upisana zadaća u njegovu narav. Zato Pieper smatra kako je potrebno ponovno otkriti čovjekovu stvorenost, nudeći samom čovjeku mogućnost novog razumijevanja samoga sebe kao jedne od Božjih ideja (Gedanken). Na takvim temeljima prepoznavanja vlastitoga bitka čovjek bi mogao uspostaviti drukčije viđenje svoje ekskluzivnosti u ovome svijetu.

Josef Pieper, kao i drugi kršćanski filozofi koji se bavi istraživanjem samoga čovjeka, ostaje vjeran misaonom konceptu stvorenosti svega što postoji. Spoznatljivost sve spoznaje promatra upravo u Božjoj stvorenosti. $\gg$ Temelj spoznavanja svega što jest, proizlazi iz stvoriteljske utemeljene Božje spoznaje i sve što je rečeno i mišljeno posjeduje karakter riječi, dakle svojstvo razumljivosti i inteligibilnosti. $\ll^{2}$ Sliku ili prasliku vlastite stvorenosti svaki čovjek nosi u sebi. Za Piepera je to izvorni temelj razumijevanja ne samo čovjeka i njegova bivstvovanja nego i svih bitnih svojstava i manifestacija ljudskih misli i djelovanja. Ideja stvaranja u svakom je slučaju stožer oko kojeg se vrti čitava njegova filozofija. Prema Pieperu glavni problem u gubljenju slike čovjeka kao Božjega stvorenja jest sam čovjek i njegovo shvaćanje svijeta i sebe. Naime, novovjekovna filozofija $s$ kojom započinje i procvat suvremene znanosti pravi otklon od biblijsko-teologijske vizije čovjeka, promatrajući to isto biće kao produkt pukog slučaja i mehaničkih zakona. Pred prirodoznanstvenim imperijalizmom i laboratorijalizmom povlači se filozofijska antropologija koja je metafizički i ontologijski utemeljena u cjelokupnoj stvarnosti.

\footnotetext{
${ }^{2}$ J. PIEPER, Unaustrinkbares Licht. Das negative Element in der Weltansicht des Thomas von Aquin, u: ISTI, Darstellungen und Interpretationen: Thomas von Aquin und die Scholastik, II, B. Wald (ur.), Hamburg, 2001., 118. Slično će reći i Augustin u Ispovijestima: »Mi, dakle, ove stvari što si stvorio vidimo zato jer jesu, a one jesu zato jer ih ti vidiš«. AURELIJE AUGUSTIN, Ispovijesti, Zagreb, 1994., 13, 38. »Zahvaljujući upravo nadnaravnom Logosu svijeta, svijet je postao racionalno sređen i stoga inteligibilan. Upravo ta inteligibilnost - spoznatljivost - svijeta, koju kršćanska teologija stvaranja i spasenja u suvislom jedinstvu neprestano ističu, dala je odlučujući poticaj uspostavi moderne znanosti. Stoga je i sama svrha moderne znanosti od početka zapisana jezikom toga Logosa, a to je upravo znanstveno, tj. racionalno istraživanje svijeta da bi se svijet upoznao kakav doista jest - uređen i spoznatljiv.« T. MATULIĆ, Mogućnosti i granice suvremene znanosti. Epistemološke i etičke analize iz teologijske perspektive, u: Bogoslovska smotra 76(2006.)2, 285.-333., 290.
} 
Stoga, egzistencijalna nesposobnost za kontemplativnu samotranscendenciju radi zadobivanja kontakta $\gg$ S onim nadljudskim, životno dajućom snagom $\ll^{3}$ kulturalno je povezana s gubitkom pojma realnosti koju Pieper naziva $\gg$ teološki utemeljenom svjetovnošću $\ll^{4}$, bez izravnog govora o tome što je uzrok, a što posljedica takvog stava. Ono što Pieper misli pod odnosom prema realnosti određeno je već kršćanskom teologijom stvaranja pod tri različita aspekta: prvo, promjena iz koncepta vječnosti svijeta prema konceptu stvaranja iz ništa; drugo, stvaranje znači da je svako biće dobro jer ga je Bog htio i jer ga voli; i treće, kršćanski pojam stvaranja pretpostavlja Stvoritelja svijeta kao temelj bića. ${ }^{5}$ Sva tri aspekta stvorene stvarnosti bila su izazov za moderne filozofe počevši od deizma i prosvjetiteljstva pa sve do Kantove kritičke filozofije koja raspravlja o teofanijskom karakteru svijeta iz perspektive ograničene ljudske spoznajne sposobnosti. Stvarna kriza zapadne ideje »teološki utemeljene sekularnosti «ili gubitka njezina utjecaja na svjetsku situaciju čovjeka otkriva se u nihilizmu »čija radikalnost postaje moguća na bazi teologijskoga koncepta stvaranja; ni na koji način ona nije misao antičke filozofije stvaranja i tako postaje mogućim misliti pojam ništa u njegovom izvanjskom obliku «. ${ }^{6}$

$S$ druge strane, Pieperovo viđenje čovjeka ne ostaje samo unutar okvira teologije stvaranja, nego je ono otvoreno najnovijim znanstvenim dostignućima, integrirajući ih u jednu smisleniju cjelinu. On to i sam govori kako se čovjeka više ne može misliti bez dostignuća evolucije, ali ni bez mitskih pripovijesti te svete predaje. Pri tome se Pieper poziva na Platonov tekst koji kaže: $\gg$ Jer jamačno je sitničavost najviše protivna duši, koja ima uvijek čeznuti za cjelovitošću, bila ona božanska ili ljudska. $\ll^{7}$

Pieperovo polazište u razumijevanju čovjeka, kako je rečeno, počiva na ideji stvorenosti svijeta i čovjeka, najjasnije dolazeći do izražaja u poglavljima njegove male knjižice Unaustrinkbares Licht. Sljedeći naslovi potvrđuju navedeno: »Biti istinit znači biti stvoren $\ll, ~ \gg$ Stvari su spoznatljive jer su stvorene $\ll, ~ \gg$ Stvari su neshvatljive jer su stvorene $\ll{ }^{8}$ Pieper kaže o odnosu između egzistirajućih stvari i njihovih arhe-

${ }^{3}$ J. PIEPER, Muße und Kult, u: ISTI, Kulturphilosophische Schriften, VI, B. Wald (ur.), Hamburg, 1998., 26.

${ }^{4}$ J. PIEPER, Was heißt christliche Abendland, u: ISTI, Miszellen, Register und Gesamtbibliographie, VIII/2, B. Wald (ur.), Hamburg, 2008., 446.

${ }^{5}$ Usp. J. PIEPER, Glück und Kontemplation, u: ISTI, Schriften zur Anthropologie und Ethik: Grundstrukturen menschlicher Existenz, V, B. Wald (ur.), Hamburg, 2007., 198. i dalje.

${ }^{6}$ J. PIEPER, Über das Ende der Zeit. Eine geschichtsphilosophische Betrachtung, u: ISTI, Schriften zur Anthropologie und Ethik: Grundstrukturen menschlicher Existenz, V, B. Wald (ur.), Hamburg, 2007., 316.

${ }^{7}$ PLATON, Država, Zagreb, 2009., 486 a 5.

${ }^{8} \mathrm{~J}$. PIEPER, Unaustrinkbares Licht. Das negative Element in der Weltansicht des Thomas von Aquin, 114.-124. 
tipova u božanskom intelektu: »Esencija stvari jest da su one stvorene misli. Ovo treba uzeti doslovno, a ne u figurativnom smislu... To bi bilo, kako se čini, Tomino shvaćanje da stvari imaju neko štostvo, neko određeno bitstvo... i da je to bitstvo stvari zapravo plod davajućeg oblika misli koja planira, odlučuje i stvara. $\ll^{9}$ Pieper tvrdi da nijekati stvaranje i stvoriteljsku misao znači nijekati istinu te pronalazi da je ova teza potvrđena u Sartreovu poznatom eseju Egzistencijalizam je humanizam. (U nastavku će biti više govora o tome.) Uostalom, za Piepera ateistički egzistencijalizam nije nikako znanstvena, ni filozofijska, nego teologijska pozicija. »Jednom riječju «, Pieper piše, $\gg$ stvari su spoznatljive jer su one bile stvorene $\ll \cdot{ }^{10}$ Baš kao što su artefakti inteligibilni jedino u odnosu prema idejama njihovog činitelja, tako je prirodni svijet inteligibilan samo u odnosu prema Bogu.

\section{Ratio i(li) intellectus - temelj razumijevanja čovjeka}

U Pieperovoj filozofiji o čovjeku na djelu su temeljna pitanja, pri čemu se tradicija, osobito ona grčko-kršćanska pokazuje uistinu plodonosnom za njegovo, a i naše mišljenje. Ratio i intellectus za Piepera su središte ljudskoga znanja pri čemu je intuitivno znanje stvarnosti (znanje koje je metafizički dar) konstitutivni element, odnosno najvažniji dio filozofijskog čina. Filozofija je kod njega usmjerena na »cjelinu svega onoga što jest $\ll .{ }^{11}$

Prema F. Tōpferu filozofijska originalnost Pieperova djela posebice se očituje u nastojanju prevladavanja jednostranosti u filozofijskome pristupu čovjeku, koja je dominirala filozofijom poslije Descartesa ${ }^{12}$, a koja se sastojala, prije svega, od razumijevanja čovjeka putem spoznaje. Spoznajno-teorijski stav potisnuo je metafizički, te se filozofija razvijala u suprotnosti prema filozofiji bitka. Stoga si Pieper u kontekstu filozofijske refleksije o autentičnoj dokolici postavlja pitanje kako se zbiva intelektualno znanje. Spoznaja je za njega bitno kontemplativnog karaktera, odnosno intelektualnog zrenja, tj. primajućeg promatranja (empfangendes Hinblicken). Prema Pieperu upravo iz Kantove filozofijske perspektive čovjek biva lišen tog intelektualnog zrenja, budući da Kant čovjekovo umno spoznavanje isključivo razumijeva diskurzivno, a to znači ne zorno. Prema Kantovu mišljenju, ljudska se spoznaja bitno ostvaruje u aktu istraživanja, zaključivanja, uspoređivanja, razliko-

\footnotetext{
${ }^{9}$ Isto, 116.

${ }^{10}$ Isto, 117.

${ }^{11}$ J. PIEPER, Was heißt philosophieren? Vier Vorlesungen, u: ISTI, Schriften zum Philosophischenbegriff, III, B. Wald (ur.), Hamburg, 2004., 29.

${ }^{12}$ Usp. F. TÖPFER, Josef Pieper on the Intellectual Foundations of Totalitarianism, u: B. SCHUMACHER (ur.), A Cosmopolitan Hermit: Modernity and Tradition in the Philosophy of Josef Pieper, Washington D. C., 2009., 85.
} 
vanja, apstrahiranja, dokazivanja. Tako je za Kanta i filozofija rad, odnosno aktivno misaono naprezanje. »Spoznaja (čovjekova umna spoznaja) bila bi, i ovo je Kantova teza, isključivo aktivnost, ništa drugo nego aktivnost. $\ll{ }^{13}$ Dakako, promatrajući spoznaju na takav način, Kant je onda morao i filozofiranje promatrati isključivo kao rad. To će Kant i izričito reći, usmjeravajući se, prije svega, protiv romantičarskog zrenja i filozofije slutnje filozofa Jacobija, Schlossera i Stolberga. U filozofiji vrijedi samo $\gg$ zakon uma, a to znači radom postići imetak. I budući da filozofija romantičara nije rad, stoga ona nije prava filozofija $\ll^{14}$

Pieper misli suprotno. On potvrđuje da iza ove aktivističke redukcije spoznaje egzistira druga dimenzija znanja koja posjeduje vrijednosti. Kako bi podupro svoju tvrdnju, on apelira na to da se razlikuju dvije vrste intelektualnog znanja, imajući na umu srednjovjekovno razlikovanje između ratia i intellectusa. Ratio je neka vrsta diskurzivnog mišljenja, traženja, istraživanja, apstrahiranja, zaključivanja, a intellectus $\gg$ je ime za um, ukoliko je on sposobnost jednostavne intuicije kojemu se ono istinito nudi kao očima krajolik $\ll .{ }^{15}$ Međutim, za stare, a time i za srednjovjekovne mislioce, ratio i intellectus uvijek su gledani povezano; kao jedna stvarnost i čovjekova bi umna spoznaja bila rezultat ratia i intellectusa. Stari su smatrali ratio bitno ljudskim, dok je intellectus pripadao području nadljudskog, odnosno pridijevao se anđelima.

Tako sv. Toma Akvinski u djelu Questiones disputatae de veritate kaže: »Iako se spoznaja ljudske duše događa na najsvojstveniji način onog ratia, ipak je u njoj jedna vrsta sudioništva u onoj jednostavnoj spoznaji o kojoj se prije svega kaže da ona ima snagu duhovnog zrenja. $\ll{ }^{16}$ Dakle, ljudsko spoznavanje ima udjela u nediskurzivnom gledanju anđela kojima je dano da opažaju stvari i ono umno kao što čovjek bez naprezanja opaža svjetlo i zvuk. »U čovjekovu spoznavanju postoji element neaktivnoga, čistoga primajućeg zapažanja - svakako ne snagom baš specifično ljudskoga, nego snagom koja nadilazi ljudsko, koja ostvaruje najviše čovjekove mogućnosti, a ipak je još uvijek 'baš ljudska'... « ${ }^{17}$

\footnotetext{
${ }^{13} \mathrm{~J}$. PIEPER, Muße und Kult, 7.

${ }^{14}$ I. KANT, Von einem neuerdings erhobenen vornehmen Ton in der Philosophie, Berlin, 1912., 390. Pieper, naime, smatra kako bi Kant jednako tako mogao i Platonovo filozofiranje proglasiti neradničkim, ako je filozofija samo umni rad, dok to isto ne bi vrijedilo za trezveni Aristotelov realizam.

${ }^{15}$ J. PIEPER, Philosophische Bildung und geistige Arbeit, u: ISTI, Schriften zum Philosophischenbegriff, III, B. Wald (ur.), Hamburg, 2004., 7.

${ }^{16}$ T. AKVINSKI, Questiones disputatae de veritate, Chicago, 1953., 15, 1.

${ }^{17}$ J. PIEPER, Muße und Kult, 9.
} 
Ipak, nije dovoljno da se čovjek zadovolji intuicijom, slušanjem proročanstva koje se otkriva biću. Prije svega, ova intuicija mora biti integrirana s ratiom. ${ }^{18}$ Prema njemu intuicija nije neracionalna, te se puno znanje stvarnosti može postići samo u povezanosti intuicije i ratia. U tom pogledu Pieper je kritičan prema određenom idealizmu koji teži prema subjektivizmu, reduciranju filozofijskog čina na ratio i isključivanju svakog drugog oblika kao neracionalnog. Esencija filozofijske misli ne nalazi se samo u činjenici intelektualnog napora diskurzivnog rada na izvjesnim problemima, nego predstavlja stvarnost koja se sama, ničim izazvana, nudi intelektu koji to znanje prima u tišini kao dar. ${ }^{19}$

\section{Ontologijsko i antropologijsko razumijevanje čovjeka}

Za Piepera, standard u svjetlu kojega je nešto nazvano antropologijskim prethodi svim drugim teorijskim spoznajama i izvodi se iz ljudske naravi. »Ako čovjekove naravi nema, na temelju čega onda samo čovjeku nešto neotuđivo pripada - i kako je onda moguće odagnati posljedicu; činite s čovjekovom što vas je volja? ${ }^{20} \mathrm{Pie}-$ perova antropologijska i ontologijska koncepcija čovjeka zapravo počinje pitanjem ljudske naravi i njezinog izvora, odnosno pitanjem razlikovanja egzistencije i esencije, problemom koji prolazi i dominira poviješću zapadne misli. Upravo u okviru antropologijske i ontologijske koncepcije ljudskoga bića treba reinterpretirati filozofijsku sliku čovjeka. ${ }^{21}$ Prema Pieperu, božansko biće oblikuje arhetip ili esenciju ljudske naravi u svome intelektu, udahnjujući esenciju egzistenciji činom volje.

Pieperova rasprava o prioritetu esencije ili egzistencije temelji se, zapravo, na razlikovanju dviju vrsta stvari $(\text { res })^{22}$ koje tvore zbilju: res naturales, koje su neovisne o ljudskom biću s obzirom na svoju narav i egzistenciju te res artificiales, čija narav i egzistencija imaju svoj izvor u intelektu i volji ljudskoga bića. ${ }^{23}$ Navedena distinkcija prisutna je već u antičkoj misli i u novije vrijeme osobito kod Sartrea. Upravo

${ }^{18}$ Usp. J. PIEPER, Muße und menschliche Existenz, u: ISTI, Miszellen. Register und Gesamtbibliographie, VIII/2, B. Wald (ur.), Hamburg, 2008., 457.

${ }^{19}$ Isto, 459.

${ }^{20}$ J. PIEPER, Über die Gerechtigkeit, u: ISTI, Schriften zur philosophischen Anthropologie und Ethik: Das Menschenbild der Tugendlehre, IV, B. Wald (ur.), Hamburg, 2006., 51.

${ }^{21}$ Ne ulazeći detaljno u međuodnos egzistencije i esencije, Aristotel podvlači jasnu razliku između onoga što jest ljudsko biće i onoga da ono jest. Dok egzistencija odgovora na pitanje onog est, esencija je zaokupljena onim što jest (quid est). Usp. ARISTOTEL, Druga analitika, u: ISTI, Organon, Beograd, 1970., II, 7, 92 b 10.

${ }^{22}$ Stvar (res) je za Piepera $\gg$ sve što je pred-metnuto (vor-liegt) osjetilnome i umnom spoznavanju, sve što ima bitak neovisno o mišljenju «. J. PIEPER, Die Wirklichkeit und das Gute, u: ISTI, Schriften zur Anthropologie und Ethik: Grundstrukturen menschlicher Existenz, V, B. Wald (ur.), 2007., 49.

${ }^{23}$ Usp. J. PIEPER, Verteidigunsrede für die Philosophie, 117.-123. 
sa Sartreom, prema Pieperu, započinje negativni proces reduciranja čovjeka na razinu proizvedenih stvari (res artificiales). Naime, Sartre smatra kako je ishodište ljudske naravi u čovjekovom intelektu koji oblikuje arhetip stvarnosti, projicirajući ga činom volje u njegovo egzistentno stanje. Ukoliko je ljudsko biće stvoritelj svih stvari, uključujući i samoga sebe i svoje naravi, što nedvojbeno proizlazi iz Sartreove filozofijske pozicije, onda je i čitava stvarnost kreacija ljudskoga intelekta. U tom slučaju svijet je konstrukcija čovjekova vlastitog duha i ništa ne egzistira samostalno. Idući u tom smjeru, moglo bi se zaključiti kako bez ljudi ni svijet ne bi postojao.

Gubitkom biblijsko-teologijske slike čovjeka iz socijalnog i filozofijskog diskursa svijet postaje a priori objektom čovjekove spoznaje. Za kvantitativni mentalitet koji reducira egzistenciju na ono mjerljivo prestaje razlikovanje »između naravnog i umjetnog ${ }^{24}{ }^{24}$ Isto će reći i Pieper, razmišljajući o Platonovu Gorgiji, kako ne postoji razlika između naravnog i umjetnog: »Razlika je između naravnog i umjetnog precijenjena. Upravo je to sekundarno. U biti to čak i ne postoji. Umjetno je sve ono što čovjek napravi, fabricira, proizvodi (automobili, hladnjaci, fizičke i filozofijske teorije, poezija); sve je ovo baš prirodno kao i sve druge stvari koje čovjek pronalazi u svijetu takve kao što je narav sama, štoviše ljudska narav. ${ }^{25}$

Kroz Pieperove spise neprestano se provlači kritika tendencije koja reducira realno na artificijelno, čin stvaranja na ljudski intelekt. Prema Pieperu realno egzistira u samome sebi neovisno o ljudskom intelektu, sugerirajući pri tome homo theoreticusa, koji je obuzet i prožet kontemplirajućom tišinom koja je inherentna realnome. »Znanje pretpostavlja čovjekovo potpuno predanje stvari. Trenutak koji definira ili sudefinira sadržaj znanja nečim drugim nego što je to objekt otvara mogućnost govora o znanju na generalan način upravo u mjeri u kojoj su ovi izvanjski elementi operativni. Ako subjekt, prema tome, nije sposoban za šutnju i nestajanja pred objektom znanja, on je u toj mjeri nesposoban za znanje. Ali objektivnost upravo znači subjektovu volju i sposobnost promatranja isključivo objekta znanja i proizvoljnog suzdržavanja od određivanja ili suodređivanja sadržaja znanja. $\ll^{26} \mathrm{Akt}$ kontemplacije (teorije) izražava činjenicu kako egzistirajuće stvari nisu proizvod ljudske subjektivnosti. To je stav otvorenosti i prihvaćanja u odnosu prema realnome što potvrđuje neshvatljivi misterij svijeta.

\footnotetext{
${ }^{24}$ M. SCHELER, Tod und Fortleben, u: ISTI, Schriften aus dem Nachlass, I., Bern, 1957., 29.

${ }^{25}$ J. PIEPER, Kümmert euch nicht um Sokrates, u: ISTI, Darstellungen und Interpretationen: Platon, I, B. Wald (ur.), Hamburg, 2002., 17.-18.

${ }^{26}$ J. PIEPER, Was heißt Akademisch, u: ISTI, Kulturphilosophische Schriften, VI, B. Wald (ur.), Hamburg, 1998., 76. i dalje.
} 


\subsection{IzVor LJUdske Naravi PREMa J. Pieperu i J. P. SARTReu}

\subsection{1. Čovjek - izvor res artificiales}

I za Piepera i za Sartrea način na koji umjetnik stvara res artificiales pomaže pri odgovoru na pitanje o izvoru ljudske naravi. Umjetnikom se tu smatra onaj koji stvara nešto u najširem smislu. Ova definicija specificirana dalje u odnosu prema ljudskom činu može se razumjeti na dva različita načina: ili kao agere, u kojem je objekt samo ljudsko biće, tj. njegov akt, ili kao facere, u kojem je objekt stvar (res) koju ljudsko biće producira. ${ }^{27}$ Upravo ova navedena dvostrukost produciranja polazišna je točka Pieperova razumijevanja umjetnikove aktivnosti. Štoviše, slijedeći antiku, Pieper ne koristi pojam stvaranja u preciznom smislu kao creatio ex nihilo, nego prije u analognom smislu čina stvaranja koji pretpostavlja minimum stvari s njezinom vlastitom naravi i s kvalitetama koje joj pripadaju i egzistiraju neovisno o misli i volji onoga koji stvara, kao supstrat potreban za obavljanje produkcije. Tako ljudsko biće ne posjeduje egzistenciju po naravi, te stoga čovjek ne može projektirati entitet u egzistenciju iz ničega. Ipak, možemo uspoređivati ljudsko biće s demijurgom koji stvara putem rada.

Stolar prije nego što počne obrađivati drvo započinje sa stvaranjem ideje oblika ili esencije konkretnog objekta, na primjer stolice. Pieper se referira na ideju kao arhetip (Vor-Form).$^{28}$ Ideja stolice ipak se u ovom trenutku potencijalno nalazi u materiji, iako njezina forma ostaje nevidljiva očima drugih. Kreativni intelekt sam spoznaje formu dok se forma eksternalizira u materiji ili komunicira prema drugom intelektu. Ideja stolice, sama po sebi, ne podrazumijeva svoju materijalnu egzistenciju. Tek aktualizacijom čina umjetnikove volje u koordinaciji s instrumentalnim uzrocima kao što su stolarove ruke ili njegov alat nastaje konkretna stolica. Prema tome, ljudski je um izvor naravi res artificiales.

Sličnu ideju nalazimo i kod Sartrea: »Kad se razmatra neki napravljeni predmet, primjerice neka knjiga ili nož za papir, taj je predmet napravio neki rukotvorac koji se nadahnuo nekim pojmom; on se pozvao na pojam 'nož za papir' i ujedno na prethodnu tehniku proizvodnje koja pripada pojmu i koja je zapravo uputa. $\ll{ }^{29} \mathrm{Sar}-$ tre zaključuje da svim res artificiales esencija prethodi egzistenciji. Za njega, kao i za Piepera, ljudski je intelekt izvor prirode res artificiales. Ljudsko biće omogućuje mjeru. Važno je naglasiti da su mjera (arhetip se nalazi unutar intelekta) i ono što je mjereno (res artificiales) uvijek identični s obzirom na njihovu narav. Esencija svake

\footnotetext{
${ }^{27}$ Usp. J. PIEPER, Die Wirklickheit und das Gute, 67.

${ }^{28}$ Usp. J. PIEPER, Wahrheit der Dinge - ein verscholener Begriff, u: ISTI, Miszellen, Register und Gesamtbibliographie, VIII/1, B. Wald (ur.), Hamburg, 2005., 421. i dalje.

${ }^{29}$ J. P. SARTRE, Egzistencijalizam je humanizam, Sarajevo, 1964., 8.-9.
} 
res artificales potječe iz ideje koja je produkt umjetnikova intelekta i koja počinje egzistirati tek kada umjetnik odluči.

\subsubsection{Intelekt - izvor ljudske naravi?}

Nakon što je, ukratko, opisan interni mehanizam rada u aktualizaciji res artificiales $\mathrm{i}$ nakon što je razvijena ovisnost o prirodi čovjeka činitelja objekta ljudskog intelekta, Pieper skreće svoju pažnju na izvor res naturales, a osobito na izvor ljudske naravi. On povlači analogiju baziranu na strukturalnoj sličnosti između aktualizacije res artificiales i res naturales, iako je svjestan analogijskog ograničenja. Prema njemu, svako je biće s obzirom na svoju narav, s obzirom na svoj oblik ili esenciju, prije $\mathrm{u}$ intelektu nego što je projektirano u egzistenciju činom volje. Svaki stvarateljski intelekt, bio on umjetnikov ili intelekt koji oblikuje res naturales, stvara u svojoj nutarnjoj dubini originalan oblik, ideju ili arhetip koji sadržava partikularnu esenciju stvari. Pojam kako je biće mišljeno, odnosno kako prima svoju esenciju iz intelekta $\gg$ ne treba razumjeti figurativno, nego doslovno. Stvoriteljska volja omogućava slobodno postojanje stvari. $\gg^{30}$ Dakle, Pieper uočava kako je priroda res artificiales ovisna o ljudskom intelektu. Po istoj analogiji on istražuje intelekt koji je izvor naravi res naturales, a osobito ljudske naravi.

Iako Pieper ne kaže eksplicitno, izvor je ove analogije Aristotelova Fizika u kojoj Aristotel potvrđuje: $\gg$ Na primjer, kad bi kuća bila među onim stvarima koje nastaju naravlju, ona bi nastala onakvom kakvom je sada po umijeću. I stvari koje su naravlju nastajale, ne samo naravlju nego i umijećem, nastale bi isto onako kao i po naravi. $\ll{ }^{31} \mathrm{Na}$ temelju principa $\gg$ umijeća imitiraju narav « moguće je zaključiti da narav mora nastaviti na način analogije tog istog umijeća. U svjetlu te analogije Pieperov argument može biti sažet Tominom tvrdnjom da $\gg$ sve stvorene stvari... stoje u odnosu prema Bogu kao produkti umijeća umjetnika $\ll .{ }^{32}$

Pieper naglašava da i sam Sartre povlači analogiju između umijeća i naravi s obzirom na njihovo djelovanje. On hvali Sartreovu filozofiju za njezinu radikalnost i jasnoću promišljanja o temi izvora ljudske naravi što vodi Sartrea dubokom nutarnjem odnosu između naravi i onoga što znači biti stvoren. ${ }^{33}$ Sartre zapravo kaže

\footnotetext{
${ }^{30}$ J. PIEPER, Warheit der Dinge. Eine Untersuchung zur Anthropologie des Hochmittelalters, u: ISTI, Schriften zur Anthropologie und Ethik: Grundstrukturen menschlicher Existenz, V, B. Wald (ur.), Hamburg, 2007., 126.

${ }^{31}$ ARISTOTEL, Fizika, Zagreb, 1988., II, 199 a 13.

${ }^{32}$ T. AKVINSKI, Summa contra gentiles, New York, 1956., II, 24.

${ }^{33}$ Pieper kaže kako je Sartre »iznenada iznova otvorio mogućnost po kojoj je nauk o stvaranju bitno skriven, a zapravo nosivi temelj klasične zapadne metafizike bitka.« J. PIEPER, Unaustrinkbares Licht. Das negative Element in der Weltansicht des Thomas von Aquin, 118.
} 
kako je nemoguće potvrditi pojam naravi, ovdje shvaćen u najširem smislu, dok simultano nijekanje pojma stvaranja još uvijek omogućuje logičku nerazdvojivost ovih dvaju koncepata. Oni su »fundamentalno međuovisni $\ll^{34}, \mathrm{tj} . \mathrm{s}$ jedne strane, svaki intelekt implicira intencionalnost, svijest nečega, nečega što spoznaje esenciju. Sartre apelira na analogiju između Božje i ljudske produktivne aktivnosti kako bi opisao odnos između naravi stvari i stvarateljskog intelekta. $\gg$ Tako je pojam čovjeka u božjemu duhu usporediv s pojmom noža za papir u duhu rukotvorca; i bog proizvodi čovjeka prema tehnikama i koncepciji kao što i rukotvorac pravi nož za papir prema nekoj definiciji i nekoj tehnici. Tako individualni čovjek ozbiljuje određeni pojam koji je u božanskom razumu. $\ll^{35}$

Teza koju su artikulirali i Pieper i Sartre može biti sažeta u tvrdnji: ako ne postoji intelekt koji oblikuje pojam stvari, entitet neće posjedovati ni esenciju ni narav. Sartre će se bez oklijevanja složiti s Pieperom koji kaže »da stvari posjeduju esenciju ako su one nacrt Stvoritelja ${ }^{36}{ }^{36}$ ili da $\gg$ ljudska narav neće egzistirati ako ne postoji Kreator koji ih planira $\ll .{ }^{37}$

Povlačeći istu analogiju Sartre isključuje mogućnost izvora naravi neartificijalne stvari u ljudskom intelektu. Ljudsko biće nije sposobno za shvaćanje ili objašnjavanje res naturales; prema tome čovjek ne oblikuje njihovu esenciju u svome intelektu, stoga, on ne može biti njihov kreator. To će Sartre na poseban način izraziti u svome djelu Mučnina, promatrajući »onaj korijen«, koji je »naprotiv postojao utoliko što ga nisam mogao objasniti «. ${ }^{38}$ Ako je ljudsko biće oblikovalo esenciju korijena unutar vlastitoga intelekta, bit će ga sposobno shvatiti i objasniti, kao što je stolar sposoban objasniti stolicu koju je napravio. Stoga, Sartre zaključuje: »čovjek ne stvara svijet, on ga samo promatra ${ }^{39}{ }^{39}$ Nakon što je isključio ljudski i božanski intelekt kao izvore subjekta, res naturales ostaju muk i tišina.

Analogija koju je Sartre ovdje primijenio samo je jedna od dviju sposobnosti koje konstituiraju ljudsku narav, naime, intelekt. On jedva ikakvu važnost pridaje bilo volji bilo njezinoj aktivnosti u produkciji stvari. Već je bilo naglašeno u analizi res artificiales kako za ideju bilo koje naravi oblikovane u intelektu koja se treba aktu-

\footnotetext{
${ }^{34}$ J. P. SARTRE, Egzistencijalizam je humanizam, 8. i dalje.

${ }^{35}$ Isto, 9.-10.

${ }^{36}$ J. PIEPER, Unaustrinkbares Licht. Das negative Element in der Weltansicht des Thomas von Aquin, 116.

${ }^{37}$ J. PIEPER, Kreatürlichkeit und menschliche Natur. Anmerkungen zum philosophischen Ansatz von Jean-Paul Sartre, u: ISTI, Schriften zum Philosophischenbegriff, III, B. Wald (ur.), Hamburg, 2004., 180.

${ }^{38}$ J. P. SARTRE, Mučnina, Zagreb, 1997., 174.

${ }^{39}$ J. P. SARTRE, Bitak i Ništo. Ogled o fenomenološkoj ontologiji, Zagreb, 2006., 62.
} 
alizirati i prijeći put od svoje nematerijalne egzistencije, tj. od samo intencionalne egzistencije, ka povijesnoj i realnoj egzistenciji, mora biti prisutan i čin volje. U svjetlu ove relacije volja - egzistencija, što je slično relaciji intelekt - esencija, može se postaviti pitanje o izvoru res naturales s obzirom na njezinu materijalnu egzistenciju.

\subsubsection{Gdje je izvor ljudske egzistencije?}

Budući da postoji nutarnja relacija između intelekta i naravi stvari, Pieper potvrđuje da iza res naturales stoji intelekt, osobito, iza ljudske naravi, intelekt Boga. Upravo to izražava maloprije citirana tomistička analogija prema kojoj je $\gg$ svaki entitet $\mathrm{u}$ odnosu prema Bogu, kao što je rad umijeća u odnosu prema umjetniku $\ll{ }^{40}$ Slijedeći Augustina i Tomu Akvinskog, Pieper naziva arhetip koji sadrži esenciju res naturales božanskom idejom. Ljudsko je biće jedna od Božjih ideja. Pieper dolazi do ovog zaključka u svojim spisima, primarno se fokusirajući na ljudsku narav, pokušavajući objasniti zašto je ljudskom intelektu nemoguće biti sam izvor svoje vlastite naravi. Ipak, čitajući između redova u drugim njegovim radovima, moguće je argumentirati, bazirajući se na teoriji znanja, elaboriranoj maloprije, koja ne implicira samo diskurzivnu metodu svojstvenu ljudskom intelektu nego i prirodno ograničava mogućnosti znanja stvorene stvari. Intelekt koji oblikuje arhetip ljudske naravi ne može biti ljudski intelekt, inače bi ljudsko biće savršeno razumijevalo svoju vlastitu narav i res naturales, što nije slučaj. Ovaj intelekt, stoga, mora biti drugo i drukčije od ljudskog intelekta. Sličnu formulaciju nalazimo i u Pieperovu habilitacijskom spisu u kojem on zastupa pojam istine stvari. ${ }^{41}$

Uzimajući u obzir istu analogiju intelekt - narav, Sartre dolazi do suprotnog zaključka s obzirom na ljudsku narav. On je ozbiljno i pravedno kritičan prema ateizmu osamnaestog stoljeća; iako oni tvrde da ne vjeruju u Boga, još se uvijek drže tradicionalne koncepcije ljudske naravi, prema kojoj ljudsko biće ostaje u posjedu ljudske naravi. ${ }^{42}$ Kao i Pieper i ovi ateisti inzistiraju da esencija prethodi egzistenciji. Sartre, koji nema interesa da se time bavi polovično, traži jasno pokazivanje svih posljedica $\gg j e d n o g ~ k o h e r e n t n o g$ ateističkog stajališta $\ll{ }^{43}$, stajališta koje nužno podrazumijeva određene implikacije za razumijevanje ljudske naravi i njezinog izvora.

${ }^{40}$ Usp. J. PIEPER, Traktat über die Klugheit, u: ISTI, Schriften zur philosophischen Anthropologie und Ethik: Das Menschenbild der Tugendlehre, IV, B. Wald (ur.), Hamburg, 2006., 5. i dalje.

${ }^{41}$ Usp. J. PIEPER, Wahrheit der Dinge. Eine Untersuchung zur Anthropologie des Hochmittelalters. Također, M. CUDDEBACK, Josef Pieper on the Truth of All Things and the World's True Face, u: B. SCHUMACHER (ur.), A Cosmopolitan Hermit: Modernity and Tradition in the Philosophy of Josef Pieper, Washington D. C., 2009., 232. i dalje.

${ }^{42}$ Usp. J. P. SARTRE, Egzistencijalizam je humanizam, 10.

${ }^{43}$ Isto, 43. 
Budući da su pojmovi esencije i stvarateljskog intelekta neraskidivo povezani jedno s drugim, Sartre zaključuje, suprotno ateističkim filozofima osamnaestoga stoljeća, kako $\gg$ nema ljudske prirode, jer nema boga da je pojmi $\ll{ }^{44}$ Sartre, strogo govoreći, ne niječe egzistenciju ljudske naravi u cijelosti. On inzistira na tome da će intelekt, koji nije sam čovjek, fiksirati ljudsku narav i odrediti je od prvog trenutka njenog postojanja. Francuski filozof odbacuje svaku narav koja bi bila protiv ljudskog bića i kojemu bi ona bila podređena, jer bi takva narav ugušila čovjekovu slobodu. U djelu Egzistencijalizam je humanizam Sartre kaže, aludirajući na svoj ateizam, »da, ako bog ne postoji, ima bar jedno biće u kojeg egzistencija prethodi esenciji, jedno biće koje egzistira prije nego što se može definirati bilo kakvim pojmom i da to biće jest čovjek... $\ll{ }^{45}$ Iako on ovdje upotrebljava izraz »bar «, ostavljajući tako otvorenom mogućnost da postoje druge stvari u kojih egzistencija prethodi esenciji, kasnije ih odbacuje. On jasno govori kako samo $\gg$ c čovjeku - i to samo u čovjeku - egzistencija prethodi esenciji ${ }^{46}{ }^{46} \mathrm{Ta}$ je tvrdnja ključna za njegovu obranu ljudske slobode.

Čini nam se da Sartre ovdje izbjegava pravo pitanje. On, doduše, tvrdi da je ljudsko biće izvor svoje vlastite naravi, ali ne tako da formira arhetip u svome intelektu. Uistinu, ljudsko biće čini samo sebe ako ono djeluje, dakle, angažira svoju slobodu, koja je apsolutno autonomna i koja je prije bilo koje aktualizacije različitih ljudskih sposobnosti. U tom pogledu, prema Sartreu, to je sloboda koja je izvor ljudske naravi. Sloboda konstituira esenciju ljudskog bića. Kao ljudsko biće koje postoji, ono oblikuje svoju vlastitu sliku, svoju narav. Sartre naglašava da, ako je čovjek samostvarajuće biće, on proizvodi svoju vlastitu narav. To je $\gg$ zato što on najprije nije ništa. On će tek poslije biti, i bit će takav kakvim će sebe učiniti... Čovjek je ne samo takav kakvim sebe pojmi nego i takav kakvim sebe hoće, i kako sebe pojmi nakon egzistencije, kako sebe hoće nakon tog poleta spram egzistencije; čovjek nije ništa drugo nego ono što od sebe čini... Čovjek je ponajprije objekt... ništa ne egzistira prije tog projekta... i čovjek će ponajprije biti ono što je projektirao da bude. $\ll{ }^{47}$ No pitanje i dalje glasi što ili tko je izvor ljudske naravi?

Sartre samo konstatira da je čovjek $\gg$ osuđen, jer nije sam sebe stvorio... $\ll{ }^{48}$, odnosno da on samome sebi ne daje vlastitu egzistenciju. »Prije bi se moglo reći... da se čudim ovom životu koji mi je darovan... darovan nizašto. $\ll{ }^{49}$ Ako je ovaj život dan

\footnotetext{
${ }^{44}$ Isto, 10.

${ }^{45}$ Isto

${ }^{46}$ J. P. SARTRE, Bitak i Ništo. Ogled o fenomenološkoj ontologiji, 55.

${ }^{47}$ J. P. SARTRE, Egzistencijalizam je humanizam, 10.-11.

${ }^{48}$ Isto, 17.

${ }^{49}$ J. P. SARTRE, Mučnina, 202. Protagonist romana Mučnina Roquentin, koji nije nitko drugi nego sam Sartre, primjećuje kad gleda stvari oko sebe da je »sve bilo puno, sve je bilo djelatno... sve
} 
subjektu, pitanje je odakle on dolazi ili, drugim riječima, gdje je volja koja ga je dovela u egzistenciju? Ako se a priori polazi od činjenice da Bog ne postoji, »moguće je $\ll^{50}$ uzeti božansku volju kao inicijatora egzistencije. Ali mogućnosti ne posjeduju volju. Sartre naglašava da je ljudsko biće bilo projektirano u svijet. ${ }^{51}$ Ali ako je čovjek bio projektiran, što ga je projektiralo? Sartre odbija odgovor na ovo pitanje.

Ako Sartre polazi ne samo od poveznice intelekt - narav nego i od poveznice volja - egzistencija, bio bi u izvjesnom smislu prisiljen daleko dublje ući u problem egzistencijalnog izvora ljudskog bića. Pieper, s druge strane, poveznicu volja - egzistencija primjenjuje i na Boga i na čovjeka, pridajući time daleko manje pažnje poveznici intelekt - esencija. Ipak, mora se naglasiti kako za njemačkog filozofa poveznica volja - egzistencija nije toliko nužna za uočavanje kako je svaka stvar esencijalno dobra i željena od Boga. ${ }^{52}$

\section{Kakva kultura?! Rada ili čovjeka!}

Naime, može se postaviti sasvim opravdano pitanje kakva je onda kultura čovjeka ako ona nije ukorijenjena u stvarateljskom intelektu, ako nije sva prožeta traganjem za čovjekovom biti ili barem interesom za ljudsko? U tom smislu Pieper apelira na zaštitu slobodnog prostora u kojem će čovjek moći biti autonoman i neće ga se promatrati samo s gledišta korisnosti. Njegov poziv izuzimanja čovjeka od samo korisnog čini nam se još aktualnijim danas, kada samo ono što donosi financijsku korist i radnu učinkovitost, a osobito statistički dobre gospodarske rezultate, ima prioritet pred svim drugim čovjekovim djelatnostima. Opravdanje za takav životni prostor nalazi se u antropologiji koja ne dopušta da ljudska osoba bude reducirana na ulogu funkcije u korist rada, odnosno na ulogu pukog proizvođača i neslobodnog građa-

se... sastojalo od postojanja... Odjednom je sve to postojalo, a onda, isto tako nenadano, nije više postojalo. Isto, 359. Roquentin niječe sve što postoji i postaje. Štoviše, on je pogođen činjenicom kako stvari nemaju želju za egzistiranjem, pružajući čitatelju opis drveća koje se suši u konačnom stanju svoje egzistencije. Čudno je kako možemo razumjeti stvarnost ako ona izgleda kao mlado drvo koje cvjeta u proljeće osvijetljeno suncem. U parku on otkriva kontigentnost stvarnosti koja je protkana apsurdnošću i pronalaskom besmisla. Upravo ta kontingencija i bezrazložnost rađaju osjećaj Mučnine. On vapi »apsurdno je da smo rođeni; apsurdno je da umiremo «. Isto, 360. Svaka je egzistirajuća stvar nestvorena. Egzistencija ne podrazumijeva nužnost. Ona je jednostavno tu. Riječ je o tome da nema razloga i ne postoji način deduciranja egzistirajuće stvari iz neke druge egzistirajuće stvari.

${ }^{50}$ Isto, 117.

${ }^{51}$ J. P. SARTRE, Egzistencijalizam je humanizam, 17.

${ }^{52}$ Usp. J. PIEPER, Kreatürlichkeit. Bemerkungen über die Elemente eines Grundbegriff, u: ISTI, Darstellungen und Interpretationen: Thomas von Aquin und die Scholastik, II, B. Wald (ur.), Hamburg, 2001., 451. i dalje. 
nina. Uistinu, osoba je pozvana da živi kao osoba, ostvarujući se kao osoba u punoj slobodi i odgovornosti kritičkog mišljenja samoga sebe.

Najprikladniji prostor takvog potpunog ostvarenja jest promocija izvorne dokolice i kontemplacije koje čovjeku ne dopuštaju reduciranje na dimenziju korisnosti, ulogu i funkciju koja prema Pieperu stvara novi proleterijat. On to objašnjava ovako: $\gg$ Dokolica nema svoje opravdanje $u$ funkcioniranju funkcionara bez smetnji i ispada, nego da čovjek (Newman bi rekao da čovjek bude džentlmen) - ne bude promatran samo unutar jedne isječene ograničene radne funkcije; čovjek je sposoban opažati svijet kao cjelinu i ostvariti samoga sebe kao biće orijentirano prema cjelini bitka. ${ }^{53}$ Upravo u dokolici nalazi se najizvorniji smisao čovjekova bića. Ona transcendira činjenje ili imanje te nastoji biti plodonosna i na raspolaganju drugima u stavu tišine, kontemplacije i ljubavi. Takav je stav daleko esencijalniji za onoga koji hoće živjeti blaženo i sretno. ${ }^{54}$

Prema Pieperu izvor je dokolice, naposljetku, u slavlju, svetkovini, i to onom kršćanskom svetkovanju. Inzistira se na potrebi i važnosti dokolice, jer ako se ona promotri u svojem krajnjem obistinjenju, u svetkovanju, slobodno se može reći misnom slavlju, ona je čovjekov susret sa samim sobom i sa svojom stvoriteljskom transcendencijom. Tek onda $\gg$ dokolica nije stav onoga koji intervenira, nego onoga koji se otvara; ne onoga koji stagnira, nego onoga koji ide dalje, koji si dopušta totalni pad $\ll .{ }^{55}$ Zato dokolica nije razonoda, razbibriga, nego prije svega stav temeljne suglasnosti sa stvarnošću, $\gg$ afirmativni pristup svijetu $\ll^{56}$, koji podrazumijeva esencijalnu dobrost bića. Dajući prednost dokolici i svetkovanju pred totalitarizacijom rada, uočava se duboki nesrazmjer između onog što čovjek trenutno jest i onoga što bi čovjek trebao biti. Nesposobnost za kontemplaciju i sklonost prema historijskome pesimizmu (ili njegovoj suprotnosti zemaljskome raju) povećava se sukladno sa smanjivanjem živog odnosa prema misteriju Božje prisutnosti. Egzistencijalni i kulturološki gubitak odnosa prema misteriju božanske prisutnosti međusobno su isprepleteni.

Paradoks ljudske egzistencije očituje se u činjenici neprestanog stvaranja potrebnih dobara, kulturalne produkcije i korisnih znanstvenih teorija, dok s druge strane, čovjek kao biće nije sposoban ispuniti mogućnost najdublje čežnje ljudskoga duha. Stoga, istinsko ljudsko spašava se udaljavanjem od svakodnevnice. U svakom slučaju ovakav pojam egzistencije zastupa i Aristotel s upozorenjem da se $\gg$ ne treba

\footnotetext{
${ }^{53}$ J. PIEPER, Muße und Kult, 26.

${ }^{54}$ Usp. isto, 37.

${ }^{55}$ Isto, 24.

${ }^{56}$ J. PIEPER, Was heißt 'christliche Abendland'?, 447.
} 
povoditi za onima koji nagovaraju da kao ljudi moramo misliti o ljudskim stvarima i kao smrtnici o smrtnima, nego — koliko god je to moguće - moramo se obesmrtiti i sve učiniti kako bismo živjeli u skladu s onim što je najizvrsnije u nama $\ll .{ }^{57}$ Isto upozorenje formulirao je i srednji vijek pojmom acediae ili žalosti, odnosno lijenosti. »Ljudskome biću s odgovornošću je dano i njegovo dostojanstvo da čovjek ne želi biti ono što bi trebao biti u konačnici ${ }^{58}$

Pieper, koji piše svoje djelo Muße und Kult u poslijeratnim vremenima, 1948., sam je svjedokom kulture koja nastoji reducirati čovjekov svijet na jednu jedinu dimenziju: radom instrumentalizirati sve čovjekove aktivnosti proglašavajući sam rad najvećom vrednotom. Tako svaka slobodna aktivnost biva promatrana u okviru produktivnosti. To je kultura koja potiče aktivizam, pokušavajući iskoristiti i eksploatirati slobodne aktivnosti do to mjere da vlada nad različitim sferama ljudskoga života. Pieper naziva podvrgavanje individualnoga utilitarnome i služinačkome novim proleterijatom. Zasigurno taj novi prikriveni proletarijat stoji pod krinkom materijalno trenutačne dobrobiti.

Pieper primjećuje kako su ljudi poslije Drugog svjetskog rata u prvi plan stavili materijalnu obnovu životnog prostora: »Zaokupljeni smo obnovom naših kuća. Ruke su nam pune posla. Trebaju li biti svi naši napori usmjereni samo na obnavljanje kuća? « ${ }^{59}$ Uzimajući ovo pitanje do kraja ozbiljno, Pieper želi upozoriti svoje suvremenike na podmuklu opasnost aktivizma koji može ugroziti ljudski život. Promovirajući rad kao najvišu vrijednost, koji je sam sebi svrha, aktivizam nastoji pokoriti ljudsku osobu kriterijima produktivnosti i profitabilnosti. Nijedno vrijeme nije prikladno za izvornu dokolicu ${ }^{60}$, a pogotovo vrijeme materijalnih obnova kakvo je i ovo tehnološko-tehnologijsko doba. No, na tragu Pieperova razmišljanja o tom konstitutivnom pojmu čovjekove svakidašnjice, upravo u jednoj dokoličarskoj raspoloživosti promovira se i sama ljudska osoba kao takva. Stoga je bitna tema svakog filozofijskog mišljenja afirmacija vitalne potrebe za autentičnom dokolicom,

\footnotetext{
${ }^{57}$ ARISTOTEL, Nikomahova etika X, 7, 1177 b 32.

58 J. PIEPER, Über die Hoffnung, 279.

${ }^{59} \mathrm{~J}$. PIEPER, Muße und Kult, 2.

${ }^{60} \gg$ Gotovo s potpunom sigurnošću može se reći da je riječ 'dokolica' u hrvatskome jeziku izvan jezične uporabe, da je iščezla iz našega jezičnog i misaonog obzorja. Ali s nestankom te riječi nije pogođena samo riječ, nego još više ona stvarnost koju ta riječ označava i izriče. Nije li neozbiljno govoriti o dokolici, kada živimo u ozbiljnim vremenima, koja stavljaju naglasak na rad, projekte, napredak ili borbu? Nije li govor o dokolici izričaj besposličarenja i nekorisnosti društvu i drugima? Nije li spas radije u radu, a ne u dokolici? Ne trebaju li kršćani radije korisno moliti i korisno raditi, a ne beskorisno dokoličariti.«I. RAGUŽ, Teologija dokolice ili o smislenosti beskorisnoga za život, u: Glas Koncila, 1. II. 2004., 4.
} 
odnosno za istinskom kulturom. ${ }^{61}$ Iako s druge strane, filozofi koji nastoje braniti i promovirati dokolicu često bivaju optuženi za poticanje ljudske lijenosti. Koja i kakva dokolica dok su gospodarski statistički podatci svakim danom sve lošiji? Može li razlog gospodarske zabrinutosti biti u nedostatku dokolice, u nedostatku ozbiljno promišljenog trenutka u tržišnom natjecanju? Ipak, čovjek nije samo radno biće i njegov se bitak ne iscrpljuje u onome svakodnevnome te je nužan iskorak prema transcendentnome i beskonačnome.

\section{Egzistencijalna neizvjesnost ljudskog bića}

U Pieperovu suprotstavljanju dokolice i rada ${ }^{62}$ može se naslutiti determinirajući i nedeterminirajući princip kao konstitutiv ljudskog bića. Iako Pieper za razliku od Sartrea, vjeruje da je ljudsko biće prirodno usmjereno prema konačnom cilju koji konstituira njegov život cjelovito, čovjek je ipak slobodan ne postići svoj cilj u stvarnosti. Čovjekova usmjerenost na cilj opisana kao blaženstvo ne implicira nužno uspjeh. Uistinu, ako subjekt nije u stanju slobodno birati ni željeti zadobiti dobro, on ipak može slobodno poduzimati djelovanja koja ga konkretno ne vode k posljednjem dobru. Štoviše, neka ga djelovanja i radnje mogu čak i odvoditi od tog dobra.

Prema Pieperu, nepostizanje toga cilja moglo bi se objasniti pomoću usporedbe, doduše nesavršene, između ljudske egzistencije i umjetnikove aktivnosti. Umjetnik nije sposoban postići zadani cilj, kao što strijelac pogađa svoju metu. Aristotel koristi istu analogiju govoreći: »griješiti se može svakovrsno... a uspjeti samo jednovrsno (zbog čega i jest jedno lako, a drugo teško - lako je promašiti cilj, teško je pogoditi ga)... ${ }^{63}$ Pieper primjećuje kako ovdje ipak postoji razlika. Dok umjetnik

${ }^{61}$ S druge strane, sam si Pieper postavlja pitanje: »Kako možemo hvaliti kontemplaciju ovozemaljskog stvaranja kada su vremena, osobito sadašnje vrijeme i vjerojatno sva prijašnja doba puna nereda, strašne nepravde, gladi, bolne smrti, ugnjetavanja i svakog oblika ljudske bijede.« J. PIEPER, Glück und Kontemplation, 214.

${ }^{62}$ Odgovarajući na Pieperov preoštri kontrast dokolice i rada, Y. Simon misli kako takvo prenaglašavanje dihotomije kulture i rada može rezultirati reduciranjem kulture na područje dekadentne dorade koja se sama izlaže »barbarskom razmišljanju « kako ju je Vico nazvao. Simona također zabrinjava pojednostavljena opozicija kulture prema radu koja njeguje koncepciju kulture kao $\gg$ neozbiljne ili kao dekorativnog poklopca za lijenost «. Y. Simon, Work, Society, and Culture, New York, 1971., 402. Simon, naprotiv, vidi u radu brojne vrline, osobito u manualnom radu. Kao individuum radnik je uvijek ovisan u svome uspjehu o pomoći drugih u podjeli rada i različitim oblicima radničkih udruženja (sindikati). Naravno, Simon je svjestan kontrasta rada i kontemplacije i Pieper nema namjeru poticanja takve kulture. Kada Simon skreće našu pažnju na pojedina područja djelovanja prema konkretnim uvjetima prakse, on ipak dijeli Pieperovo uvjerenje kako filozofija nije specijalizirano područje usmjereno na pitanja epistemologijskog opravdanja.

${ }^{63}$ ARISTOTEL, Nikomahova etika, II, 5, 1106 b 28.-32. 
prakticira svoje umijeće sve vrijeme oskudno ostajući u posjedu tog umijeća, čovjek ne može živjeti poročno, a nastavljajući posjedovati vrlinu, nastavljajući biti dobrom osobom, prakticirajući umijeće dobra življenja i, štoviše, ispunjavajući samoga sebe. ${ }^{64}$

Dok je na putu, čovjek je obilježen egzistencijalnom nesigurnošću. ${ }^{65}$ Čovjek ostaje u stanju nesigurnosti s obzirom na realizaciju svog svojstvenog napredovanja kojeg Pieper razumijeva kao krepostan život. Unatoč činjenici da stalno vježbanje u kreposti implicira povećanu vjerojatnost da ju subjekt neće izgubiti, čovjek ipak nikada ne posjeduje krepost neopozivo i definitivno. On bi ju u biti mogao izgubiti gradualno, obavljanjem izvjesnog broja činova koji su suprotni kreposti, te bi mogao postati indiferentan i poročan, zamjenjujući prvi habitus drugim.

Nesigurnost s obzirom na potpunu puninu ljudskoga bića zahtijeva novu dimenziju u kontekstu Pieperova pojma kako teologijske kreposti doprinose krajnjem cilju, koje on opisuje kao nadnaravno blaženstvo, iako to blaženstvo ne niječe čovjekovu prirodnu puninu koja se ostvaruje prirodnim moralnim krepostima. Nesigurnost $\mathrm{u}$ ovom kontekstu tiče se, $\mathrm{s}$ jedne strane, individualnog nedostatka povjerenja u potpuno Drukčijeg koji samog sebe daje individualnome i koji je izvor teologijskih kreposti i, s druge strane, mogućnosti individuuma da odbije dar ovih kreposti koje ga usmjeravaju primanju dara od samoga Boga. Nesigurnost također može nastati na prirodnoj razini ako čovjek svojim vlastitim naporom ne postiže cilj prema kojemu je odlučio težiti, onaj cilj čije posjedovanje radikalno ovisi o drugima. U slučaju u kojem individuum postiže dobro svojim vlastitim sredstvima, nesigurnost dolazi ili iz nedostatka, ili iz nepovjerenja u svoje vlastite sposobnosti, ili iz izvanjskih događaja. Stoga Pieper kaže kako ovo historijsko-temporalno biće egzistira u konstitutivnom obliku neizvjesnosti, postajanja, onog još-ne, nade. Neizvjesnost ljudskog stanja ne može biti eliminirana. Ona može biti samo prevladana principom nade. ${ }^{66}$

Prema Pieperu čovjek prebiva u svijetu ne u tjeskobno skeptičnoj sumnji ni u udobnoj izvjesnosti sveobuhvatne vizije, nego u nadi. Čovjekov je svijet »cijela stvarnost usred koje čovjek živi licem u lice s cjelokupnošću egzistirajuće stvari; razumijevanje koje nije dano u savršeno potpunom razumijevanju, nego samo u iščekivanju nade $\ll \cdot{ }^{67}$ Ono što Pieper predlaže na temelju čitanja Akvinskog jest metafizika nade u kojoj se može sudjelovati zahvaljujući brojnim zajedničkim praksama.

\footnotetext{
${ }^{64}$ Aristotel opetovano ponavlja da je čovjekovo dobro, njegova sreća u vođenju kreposnog života, »u potpunom životu «. Isto, I, 6, 1098 a 20.

${ }^{65} \mathrm{O}$ temi egzistencijalne nesigurnosti: O. F. BOLNOW, Neue Geborgenheit, Das Problem einer Überwindung des Existentialismus, Stuttgart, 1955., osobito 20. i 160.

${ }^{66}$ Usp. J. PIEPER, Über die Hoffnung, 262.

${ }^{67}$ J. PIEPER, Was heißt philosophieren? Vier Vorlesungen, 43.
} 
Stoga Pieper kaže kako »čuđenje znači biti na putu... U toj povezanosti nijekanja i potvrđivanja čuđenje očituje strukturu nade, oblik nade koja je upravo svojstvena filozofiranju, štoviše, samoj čovjekovoj egzistenciji. ${ }^{68}$ Slijedeći Akvinskog koji opetovano inzistira na parcijalnom shvaćanju božanskog putem filozofijskog diskursa, Pieper uvodi temporalni element u samu srž kontemplativnog života i stoga povezuje praksu same filozofije s vrlinom nade. Zato je ćudoredno djelovanje »izvanjskost onoga što čovjek može biti. Ono je ispunjenje čovjekova 'moći biti... Ćudoredan čovjek iz najnutarnjijeg nagnuća biti ostvaruje dobro svojim činom. ${ }^{69}$

Nada ne može postojati sve dok je njezin predmet ontologijski konstituiran onim još-ne koje izražava temporalnost u kojoj je ona projektirana, što se najbolje vidi na primjeru Blochova ${ }^{70}$ razumijevanja ove temeljne odrednice čovjekova bića. Ontologijska otvorenost tubitka prema budućnosti u kojoj postoje različite mogućnosti bića temelj su čina nade. Bez nje bi ljudsko biće bilo statično. Čovjek bi prestao biti $\gg n a$ putu« (in via). ${ }^{71}$ Upravo slobodna projekcija tubitka prema mogućnosti čini nadu mogućom. Poput temporalnog bića, tubitak je uhvaćen između prošlosti i budućnosti, između svoga izvora i cilja, bez obzira je li determinirani cilj inherentan njegovoj naravi ili je slobodno izabran. Stoga jaz između nade i vizije ocrtava budućnosti orijentiran karakter kršćanskog života. Prema Pieperu, mi smo »lutalice i putnici; to je srž naše stvorene egzistencije $\ll{ }^{72}$ Potreba za nadom označava »odsutnost punoće $\ll$, , $\gg$ našu blizinu prema ništavilu $\ll i \mathrm{i} \gg$ našu orijentaciju prema punoći . $^{73}$

Pieper pažljivo istražuje i pronalazi velik broj argumenata o koristi povijesnoga napretka koji je konstruiran kao kretanje prema univerzalnom društvu, društvu

${ }^{68}$ Isto, 49.-50.

${ }^{69}$ J. PIEPER, Über das christliche Menschenbild, u: ISTI, Religionsphilosophische Schriften, VII, B. Wald (ur.), Hamburg, 2000., 98.

${ }^{70}$ Zajedno s Blochom Pieper zastupa i ontologiju postajanja još-ne-bitka koju oni primjenjuju na ljudsko biće koje je definirano dinamičkim stanjem težnje prema Totumu ili summum bonum, prema punoj realizaciji. Ipak, dvojica njemačkih mislilaca razlikuju se jedan od drugoga s obzirom na konačni cilj i sadržaj onoga što čovjek treba biti te način poimanja ljudske naravi. Blochovo razmišljanje, prije svega, ima svoj temelj u dijalektičkom materijalizmu, odnosno u interpretaciji lijevog krila aristotelizma afirmiranog kod Avicene i posebno Averroesa. Konkretan cilj onog još-ne kod Blocha jest poboljšanje svijeta i ljudskog stanja. Riječ je o progresivnoj dinamici prema zemlji otaca u kojoj će svi antagonizmi nestati, zemlji otaca koja se ostvaruje jedinstveno kroz praksu koju Bloch opisuje kao apsolutni identitet između ljudskog bića i prirode, »naturalizaciju čovjeka, humanizaciju prirode $\ll$. E. BLOCH, Princip nada, Zagreb, 1981., 365.

${ }^{71}$ J. PIEPER, Über die Hoffnung, 257.

${ }^{72}$ Isto, 258.

${ }^{73}$ Isto, 259. 
pravih odnosa među osobama. Pieper zaključuje: $\gg$ Ako je zemaljska egzistencija strukturirana prema onome 'što još nije u bivanju' i ako je čovjek kao putnik istinski 'na putu' sve do trenutka smrti, onda je ova nada koja je identična s našim samim bivanjem ili besmislena ili pronalazi svoje krajnje ispunjenje s druge strane smrti. $\ll^{74}$

\section{Zaključak}

Pitanje o čovjeku nije jedno među brojnim filozofijskim pitanjima, nego temeljno antropologijsko, kulturologijsko, moralno... pitanje s kojim sva misao o čovjekovom dostojanstvu i položaju u svijetu počinje. Tko je ili što čovjek, kakvo je on biće, ne odlučuje se ponajprije u teorijskoj filozofiji ni u području pojedinih empirijskih znanosti, nego se tiče samoga čovjeka kao bića koje je usmjereno na Drugoga. Ni na koji način nije sporna uloga i funkcija koju imaju sve druge znanosti. No, s druge strane, čovjek nije stvar, stoga se njegova složenost bića ne može konstatirati empirijski, statistički, gospodarski, politički... Čovjek je putnik projektiran u temporalnost između prošlosti i budućnosti, između svoga izvora i svoga konačnog cilja, usmjeren prema realizaciji mogućnosti. Čovjek putuje prema konačnom cilju, prema punome bitku $\mathrm{i}$ (li) prema punom posjedovanju, upisanom u dubini njegove naravi, koji podrazumijeva čovjekovu slobodnu aktualizaciju totaliteta da se bude. ${ }^{75}$ Upravo zbog ove antropologijsko-ontologijske strukture, sve dok je čovjek živ i živi, nalazi samog sebe »na putu«. On ne može izbjeći dinamičkoj, temporalnoj ontologiji još-ne-bitka koja ga usmjerava prema budućnosti u kojoj se on nada da će postići puninu mogućeg bitka, puninu svoje osobe, samo ako razvija ono što jest, aktualizirajući i ostvarujući svoje biće, svoj projekt. Čovjek to čini, kaže Pieper, prakticirajući ljudske vrline koje omogućuju takvu aktualizaciju mogućnosti. Vrline su pokušaj realiziranja i održavanja onoga što jest ljudsko biće i što želi biti po naravi. Čovjek se razvija u svojoj specifičnosti, za kojega biti čovjekom kao takvim znači da je on sam sebi zadan kao zadaća koju ne može izbjeći. Prepoznavajući samoga sebe u prirodnoj datosti svoga tubitka, čovjek otkriva čovještvo koje mu je postavljeno kao cilj i zapovijed njegova života.

\footnotetext{
${ }^{74}$ J. PIEPER, Hoffnung und Geschichte. Fünf Salzburger Vorlesungen, u: ISTI, Kulturphilosophische Schriften, VI, B. Wald (ur.), Hamburg, 1998., 436. »Sama modernost koja ne uspijeva u ispunjavanju nade potiče, oponašajući kršćanstvo, u čovječanstvu generirajući oblik i stupanj očaja svojstven moderni.« J. G. GODFREY, The Future of Pieper's Hope and History, u: B. N. SCHUMACHER (ur.), A Cosmopolitan Hermit: Modernity and Tradition in the Philosophy of Josef Pieper, Washington, D. C., 2009., 149.

${ }^{75}$ Usp. J. Pieper, Die Aktualität der Kardinaltugenden: Klugheit, Gerechtigkeit, Tapferkeit, Maß, u: ISTI, Miszellen, Register und Gesamtbibliographie, VIII/1, B. Wald (ur.), Hamburg, 2005., 292.
} 


\title{
THE IDEA OF MAN IN THE PHILOSOPHY OF JOSEF PIEPER
}

\author{
Franjo MIJATOVIĆ*
}

Summary: The article will primarily point to several basic assumptions and implications of Pieper's understanding of man, his essence, and his position in the world, in an attempt to explain through a synthesizing philosophical-theological vision the phenomena such as culture, work, morals, leisure, etc. Special attention will be paid to Pieper's understanding of the human being, that is, the theory of human nature, which he understands as a theological project that needs to be brought to actualization. Human beings, if they are part of the divine creation, are directed toward a certain final end, to an intimate bond with the Creator. Josef Pieper, therefore, shapes the philosophical anthropology around the natural state of man's Being, whereby man reveals his humanity in an ontological temporality as the goal and mission of his life.

Keywords: Josef Pieper, metaphysics of creation, human nature, J. P. Sartre, leisure, to be on track.

\footnotetext{
*Franjo Mijatović, Ph. D., Theology of Rijeka, Dislocated Studies of Catholic Faculty of Theology, University of Zagreb, Omladinska 1, 51000 Rijeka, Croatia, fran_mij@yahoo.com
} 